\title{
Kinetics and Mechanism of the Pyridinolysis of Aryl Cyclobutanecarboxylates in Acetonitrile
}

\author{
Han Joong Koh," Kwang Lae Han," Hai Whang Lee, and Ikchoon Lee ${ }^{\ddagger}$ \\ Department of Science Education, Chonju National University of Education, Chonju 560-757. Korea \\ ${ }^{\top}$ Department of Science Education, Kwangin National University of Education, Kwangiu 500-703, Korea \\ ثDepartment of Chemistry, lhha University, Inchon $402-751$, Korea
}

Received February 20, 2002

\begin{abstract}
Kinetic studies of the reaction of Z-aryl cyclobutanecarboxylates with X-pyridines in acetonitrile at $55.0^{\circ} \mathrm{C}$ have been carried out. The reaction proceeds by a stepwise mechanism in which the rate-determining step is the breakdown of the zwitterionic tetrahedral intermediate, $\mathrm{T}^{-}$. These mechanistic conclusions are drawn based on (i) the large magnitude of $\rho_{\mathrm{x}}$ and $\rho_{7 .}$. (ii) the positive sign of $\rho_{x}$. and the larger magnitude of $\rho_{x y}$ than normal $\mathrm{S} \times 2$ processes, (iii) a small positive enthalpy of activation, $\Delta H^{\neq}$, and a large negative, $\Delta S^{\neq}$, and lastly (iv) adherence to the reactivity-selectivity principle (RSP) in all cases.
\end{abstract}

Keywords: Aryl cyclobutanecarboxylates, Stepwise mechanism, /witterionic tetrahedral intermediate, Cross-interaction constant.

\section{Introduction}

Although the mechanisms of aminolyses of acetate' and benzoate ${ }^{2}$ esters, and diaryl $l^{3}$ and alkyl aryl carbonates ${ }^{4}$ are well understood, much less is known about the aminolysis of small ring cyclo ester compounds.

We have recently studied the kinetics of the aminolysis of aryl cyclopropanecarboxylates, ${ }^{5}$ and aryl cyclobutanecarboxylates." We have found that the reactions of aryl cyclopropancarboxylates $^{5}$ and the aryl cyclobutanecarboxylates ${ }^{6}$ proceed through a stepwise mechanism with late-limiting expulsion of a leaving group (aryl oxides) from a tetrahedral intermediate, $\mathrm{I}^{+}$, with a hydrogen-bonded, four-center transition state.

The Bronsted plots for the aminolysis of carbonyl compounds are often curved with a change in slope from a large $\left(\beta_{\text {uuc }} \geq 0.8\right)$ to a small $\left(\beta_{\text {uuc }} \leq 0.3\right)$ value, which can be attributed to a change in the rate determining step from breakdown to formation of a tetrahedral zwitterionic intermediate $\left(\mathrm{l}^{+}\right)$in the reaction path as the amine basicity is increased. ${ }^{7}$ The stepwise mechanisın with rate-limiting expulsion of leaving group $(\mathrm{LZ})$ from $\mathrm{T}^{-}(\mathrm{I})$ is more likely to be observed<smiles>[R]C([14CH3])([18OH])[18OH]</smiles>

in the aminolysis of a carbonyl compound with (i) a stronger electron acceptor acyl group. RY, (ii) a poor leaving group. $L Z^{8}$ and (iii) a more weakly basic (or nucleophilic) amine $(\mathrm{XN}){ }^{\text {sh.c }}$ However, the effect of the acyl group. RY, on the

"Corresponding Author. E-mail: hankoh(ojnue.ac.kr mechanism is subtle and is not quite straight-forward, since the effect can be both on the substrate and the intermediate, $\mathrm{I}^{+}$, and the electronic effect can be either inductive or resonance delocalized, or both. This is the reason why it is rather difficult to predict the mechanism simply by taking account of the stereoelectronic effect of the acyl group, RY.

In view of the importance of predicting the effects of the acyl group on the mechanism of aminolysis of carbonyl compounds, we have used many different acyl groups in our studies of the aminolysis mechanism. ${ }^{5,6.80,9}$ In previous work, we investigated the effect on the mechanism of the reaction of a cyclobutane group, $\mathrm{RY}=$ cyclo- $\mathrm{C}_{1} \mathrm{H}_{7}$, with benzylamines in acetonitrile ${ }^{(6)}$ and found that the cyclobutyl group leads to stepwise aminolysis with rate-limiting breakdown of the intermediate, $\mathrm{T}^{+}$. In this paper, we extend our work to the pyridinolysis of aryl cyclobutanecarboxylates, II, with pyridines (Py) in acetonitrile (eq. 1).

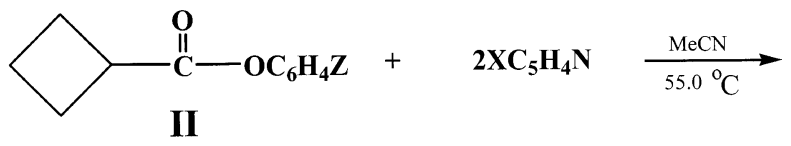

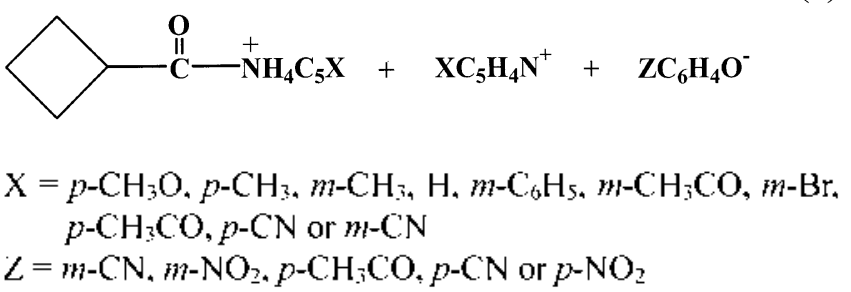

The purpose of the present work is to further explore the effect of the acyl group on the pyridinolysis mechanism by investigating the structure-reactivity behavior of aryl cyclobutanecarboxylates in acetonitrile. We are interested in the effects of the small ring acyl group on the mechanism. especially on the sign and magnitude of the cross-interaction 


$$
\begin{gathered}
\log \left(k_{\mathrm{XZ}} / k_{\mathrm{HH}}\right)=\rho_{\mathrm{X}} \sigma_{\mathrm{X}}+\rho_{\mathrm{Z}} \sigma_{\mathrm{Z}}+\rho_{\mathrm{XZ}} \sigma_{\mathrm{X}} \sigma_{\mathrm{Z}} \\
\rho_{\mathrm{XZ}}=\partial \rho_{\mathrm{Z}} / \partial \sigma_{\mathrm{X}}=\partial \rho_{\mathrm{X}} / \partial \sigma_{\mathrm{Z}}
\end{gathered}
$$

constant. ${ }^{15} \rho_{X z}$ in equs. (2a) and (2b). where $X$ and $Z$ are the substituents in the nucleophile. pyridine. and leaving group. aryl oxide, respectively. Furthermore. the activation parameters, $\Delta H^{z}$ and $\Delta S^{\prime z}$. are also determined since they can provide valuable information regarding the transition state (TS) structure.

\section{Results and Discussion}

The psendo-first-order rate constants observed $\left(k_{\mathrm{obs}}\right)$ for all the reactions obeyed eq. 3 with negligible $k_{0}(\equiv 0$ ) in acetonitrile. The second-order rate constants, $k \cdot\left(\mathrm{M}^{-1} \mathrm{~s}^{-1}\right)$ summarized in Table 1, were determined using eq. 3 with at least five

$$
k_{\mathrm{ols}}=k_{0}+k_{\mathrm{R}}[\mathrm{PY} \mathrm{y}]
$$

pyridine concentrations. [Py]. No third-order or higher-order terns were detected, and no complications were found in the determination of $\mathrm{k}_{\mathrm{obs}}$ and also in the linear plots of eq. 3 . This suggests that there are no base-catalysis or noticeable side reactions and the overall reaction follows the route given by eq. 1 .

The $\mathrm{p} K \mathrm{a}$ values of pyridines (Table 1 ) used in the Bronsted plots were those determined in water. Thus the Bronsted coefficients in Table 1 ( $\beta_{\text {Sinui }}$ ) could be in error since the rate data in Table 1 (in acetonitrile) should be plotted using $\mathrm{pKa}$ values measured in acetonitrile. However our recent theoretical studies of solvent effects on the basicity of substituted pyridines at the IPCM/B3LYP/6-3IG* level ${ }^{11}$ have shown that there is a constant $\mathrm{pKa}$ difference of $\triangle \mathrm{pKa}=$ $\mathrm{p} K \mathrm{a}(\mathrm{MeCN})-\mathrm{pKa}\left(\mathrm{H}_{2} \mathrm{O}\right)=7.7$ due mainly to the $\mathrm{H}^{+}$ion solvation free energy difference of $10.5 \mathrm{kcal} \cdot \mathrm{mol}^{-1}$ between acetonitrile and water. The plot of $\mathrm{pKa}(\mathrm{MeCN}) \& \mathrm{pKa}\left(\mathrm{H}_{3} \mathrm{O}\right)$ exhibited a straight line of near unity (1.02) slope so that the
Bronsted coefficients determined by the plot of $\log k(\mathrm{MeCN})$ against $\mathrm{pKa}\left(\mathrm{H}_{3} \mathrm{O}\right)$ should be almost the same as those against $\mathrm{pKa}(\mathrm{MeCN}){ }^{12}$ Moreover. the plots of $\mathrm{p} K \mathrm{a}(\varepsilon)$ (in 5 solvents including water) is $\sigma$ gave the slopes. $\rho_{\mathrm{s}}(\varepsilon)$, which is linear with the Onsager dielectric function. $(\varepsilon-1) /(2 \varepsilon+1)$, eq. 4 with correlation coefficient of $0.999(n=5)$. This means that the specific hydrogen-bonding solvation component is not important in the solvation effect on the ionization equilibria of pyridinum ions in water. The slope, $\rho_{s,}$ is thus solely dependent on the bulk solvent effect $(\varepsilon)$ and for $\varepsilon=78.3^{\text {is }}$ (water) and $\varepsilon=37.9^{13}$ (acetonitrile) the $\rho_{\mathrm{s}}$ values are quite similar being -8.9 and -9.1 , respectively. This provides evidence in support of correlating the rate data determined in acetonitrile with the $\mathrm{p} K$ a values measured in water.

$$
\rho s=14.6\left[\frac{\varepsilon-1}{2 \varepsilon+1}\right]-16.1
$$

The excellent linearities found in the Bronsted plots using ten nucleophiles $(r \geq 0.998)$. standard devation $\leq 0.01$ ) in Figure 1 lend more credence to our procedure. In Figure $l$ is demonstrated a Bronsted-type plot for the reaction of aryl cyclobutanecarboxylates with pyridines run in acetonitrile. The linear Bronsted-type slope should correspond to the mechanism change does not occur in the present pyridinolysis. ${ }^{2.4 .15}$ We therefore think that our $\beta_{\mathrm{X} \text { (nuc) }}$ values in Table I represent reasonable and meaningful values. The Hanmett $\left[\rho_{\mathrm{X}}\left(\rho_{\mathrm{nuc}}\right)\right.$ and $\left.\rho_{\mathrm{Z}}{ }^{-}\left(\rho_{\mathrm{g}}{ }^{-}\right)\right]$values (Figures 2 and 3 ) coefficients, are also shown in Table 1 .

The activation parameters. $\Delta H^{*}$ and $\Delta S^{*}$ (Table 2), were determined based on the kv values at three temperatures. 35 . 45 , and $55.0^{\circ} \mathrm{C}$. These are comparable to those corresponding values for the reactions of aryl cyclobutanecarboxylates with bezylamines in acetonitrile. ${ }^{b}$

Rates are faster with a stronger nucleophile $\left(\delta \sigma_{x}<0\right)$ and nucleofuge $\left(\delta \sigma_{z}>0\right)$ as is expected from a typical nucleo-

\begin{tabular}{|c|c|c|c|c|c|c|c|c|}
\hline$X$ & $\mathrm{pKa}^{a}$ & $Z=m-C N$ & $n t-\mathrm{NO}_{2}$ & $p-\mathrm{CH}_{3} \mathrm{CO}$ & $p-\mathrm{CN}$ & $p^{-N_{2}}$ & $\rho_{z}^{b}$ & $\beta_{z^{\prime}}$ \\
\hline$p-\mathrm{CH}_{3} \mathrm{O}$ & 6.58 & 20.1 & 33.1 & 97.7 & 177 & 833 & 2.33 & -1.14 \\
\hline$p-\mathrm{CH}_{3}$ & 6.03 & 3.89 & 11.5 & 31.6 & 81.3 & 379 & 2.81 & -1.35 \\
\hline$m-\mathrm{CH}_{3}$ & 5.67 & 2.95 & 5.13 & 16.2 & 51.3 & 224 & 2.77 & -1.33 \\
\hline $\mathrm{H}$ & 5.21 & 1.05 & 2.51 & 6.46 & 15.8 & 72.4 & 2.61 & -1.26 \\
\hline${ }_{n+}-\mathrm{C}_{5} \mathrm{H}_{5}$ & 4.92 & 0.490 & 1.51 & 3.31 & 9.77 & 49.0 & 2.80 & -1.35 \\
\hline$m-\mathrm{CH}_{3} \mathrm{CO}$ & 3.17 & 0.0126 & 0.0589 & 0.162 & 0.630 & 4.17 & 3.52 & -1.69 \\
\hline$m-\mathrm{Br}$ & 2.85 & 0.00759 & 0.0347 & 0.0977 & 0.309 & 2.82 & 3.56 & -1.72 \\
\hline$p-\mathrm{CH}_{3} \mathrm{CO}$ & 2.38 & - & - & 0.0417 & 0.166 & 1.23 & 3.61 & -1.06 \\
\hline$p-\mathrm{CN}$ & 1.86 & - & - & - & 0.0813 & 0.630 & 3.30 & -1.09 \\
\hline$n-\mathrm{CN}$ & 1.35 & - & - & - & 0.0331 & 0.269 & 3.37 & -1.11 \\
\hline$p x^{d}$ & & -5.10 & -4.47 & -4.45 & -3.88 & -3.55 & $\rho_{x z^{\prime}}=2.05$ & \\
\hline$\beta x^{e}$ & & 0.91 & 0.79 & 0.79 & 0.72 & 0.66 & & \\
\hline
\end{tabular}
philic substitution reaction. The rates are $\sim 1.3$ times slower than those for benzylamines ${ }^{6}$ under the same reaction condi-

Table 1. Rate constants, $k_{k}\left(\times 10^{3} \mathrm{M}^{-1} \mathrm{~s}^{-1}\right)$, for the reactions of $Z$-aryl cyclobutanecarbosylates with $\mathrm{X}$-py ridines in acetonitrile at $55.0^{\circ} \mathrm{C}$

"In water at $25.0^{\circ} \mathrm{C}$. Fischer, A.; Galloway. W. J.: Vaughan. J. J. Chem. Soc. 1964. 3591. Hong. S. W.: Kolı. H. J.: Lee. I. J. Plnus. Org. Chem. 1999.12. 425. "Signa $\left(\sigma\right.$ and $\sigma^{\prime}$ ) values were taken from: Hansch. C.: Leo. A.; Taft, R. W. Chent Rev: 1991.91. 165. Correlation coefticients are better than 0.994 in all cases. "The $\mathrm{p} K \mathrm{a}$ values are taken from: Albert, A.: Serjeant. E. P. The Determination of Ionization Constants, $3^{\text {red }}$ ed.. Chapman and Hall, London. 1984. p. $45 . \mathrm{Z}=p-\mathrm{CH}_{2} \mathrm{CO}$ is excluded. The source of $\sigma$ is the same as for fontnote $\mathrm{b} . \mathrm{X}=m-\mathrm{CN}$ is excluded. Correlation coefficients are better than 0.994 in all cases. "Correlation coefficients are better than 0.998 in all cases. ${ }^{\circ}$ Correlation coefficient is better than 0.997. 


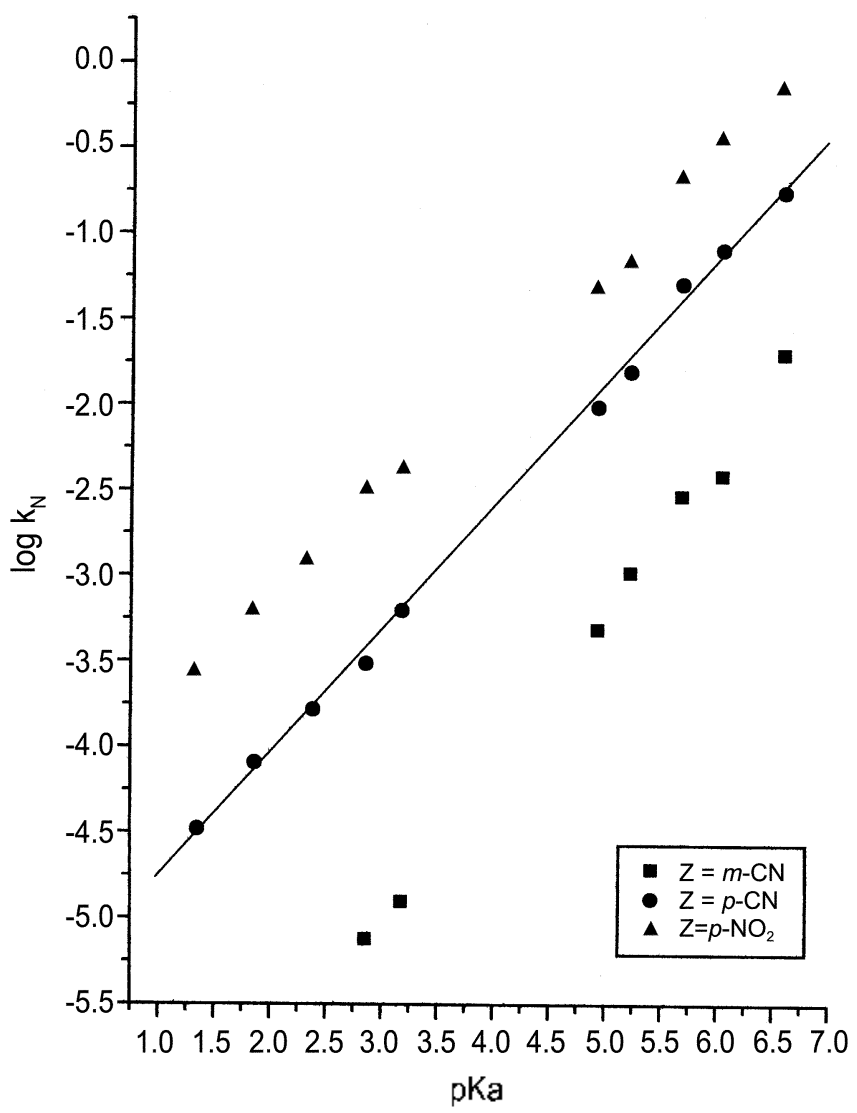

ligure I. Bronsted plots $\left(\beta_{X}\right)$ for the pyridinolysis of 7-aryl cyclobulanecarboxylates with $\mathrm{X}$-psridines $\left(\mathrm{XC}_{5} \mathrm{IL}_{4} \mathrm{~N}\right)$ in $\mathrm{MeCN}$ at $55.0^{\circ} \mathrm{C}$.

tions. This could be due to a larger basicity of the benzylanine $(\mathrm{pKa}=9.38)$ relative to that of the pyridine $(\mathrm{p} K \mathrm{a}=$ 5.21 ) in the nucleophiles.

The results in Table 1 reveal that the magnitude of $\rho_{\mathrm{x}}$ is quite large: it ranges from -3.55 to -5.10 (the corresponding values are -0.76 to -1.90 (phenyl benzoates - benzylamines)), ${ }^{2 a}$ -2.85 to -4.83 (phenyl carbonates + benzylamines) ${ }^{20}$ after allowing for a fall-off factor of $2.8^{14}$ for the non-conjugating intervening group $\mathrm{CH}_{2}$ in benzylamine(relative to pyridine). This large magnitude of $\rho_{\mathrm{N}}\left(\rho_{\mathrm{nuc}}\right)$ is also reflected in the similarly large magnitude of $\beta_{X}\left(\beta_{\text {nuc }}\right)=0.66-0.91$ (the corresponding values are $0.25-0.70$ (phenyl benzoates + benzyl-

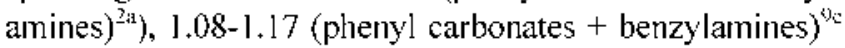
and 1.06-1.83 (phenyl furoates + benzylamines). ${ }^{\%}$ and $1.33-$ 2.09 (aryl cyclobutanecarboxylates + benzylamines). ${ }^{6}$. These large magnitudes of $\rho_{\mathrm{X}}$ and $\beta_{\mathrm{X}}$ are indicative of a stepwise mechanism with a rate-limiting breakdown of a zwitterinonnic tetrahedral intermediate, $I^{-2.40 .15}$ (Scheme 1).

Figure 3 shows the Hammett plots for variations of substituent in the leaving group, $\sigma_{L}\left(\sigma_{L^{-}}\right)$. The importance of the leaving group departure in the rate-determining step in reflected in the better Hammett correlations with $\sigma_{L}^{-}$than with $\sigma_{L}$ and large magnitude of $\rho_{L}{ }^{-}(=2.33-3.61)$ suggesting a strong negative charge development in the aryl oxide leaving group with a relatively large extent of bond cleavage in the IS $\left(\beta_{L}=-1.06 \sim-1.72\right)$. Also these large $\rho_{L}{ }^{-}$values are

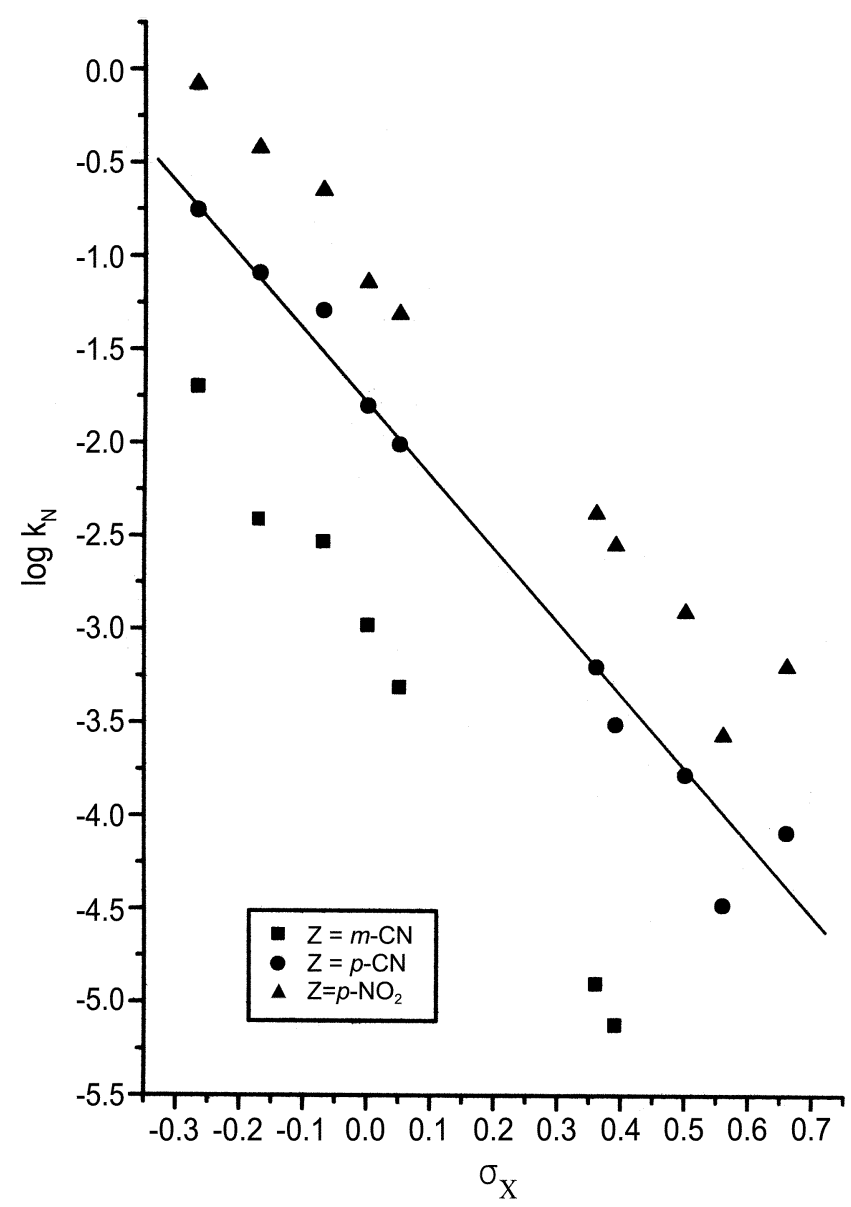

Figure 2. Hammett plots $\left(\rho_{x}\right)$ for the pyridinolysis of Z-ary] cyclobutancearhoxylates with $\mathrm{X}$-pyridines $\left(\mathrm{XC}_{\mathrm{s}} \mathrm{H}_{4} \mathrm{~V}\right)$ in $\mathrm{MiCN}$ at $55.0^{\circ} \mathrm{C}$.

again indicative of the stepwise mechanism with a ratelimiting breakdown of a zwitterionic tetrahedral intermediate, $T=($ Scheme 1$) .^{2.4 \%} .15$

The 52 rate constants $\left(k_{\mathrm{N}}=k_{X z}\right)$, in Table $\mathrm{l}$ are subjected to multiple regression analysis using eq. 2 . We note that the correlation is quite satisfactory with the cross-interaction constant. $\rho_{\mathrm{X}<}$ of +2.05 . This values is also similar to that for the reactions of aryl cyclobutanecarboxylates with benzylamines $\left(\rho_{X z}=+1.02\right){ }^{6}$ under the same reaction conditions. The cross-interaction between the substituents $X$ in the nucleophile and $Z$ in the substrate is reduced by a factor of two due to an intervening non-conjugative $\mathrm{CH}_{2}$ group in benzylamines, albeit transition state may be similar for the two series. ${ }^{14}$

Previously we have shown that in the $S_{i} 2$ process or in the rate-limiting formation of an intermediate the $\rho_{\mathrm{X} L}$ is negative, but in a stepwise mechanism with a rate-limiting breakdown of the tetrahedral intermediate it is large positive. ${ }^{0.9}$ The cross-interaction constant $\rho_{\mathrm{X}<}$ obtained was positive and large at +2.05 . This provides further strong support for the proposed mechanism comes from a large positive cross-interaction constant $\rho_{X x_{.} .}{ }^{5.6 \% .16}$ Since an electron acceptor in the nucleophile, $\delta \sigma_{X}>0$ (in the nucleofuge, $\delta \sigma_{L}$ $>0)$ leads to an increase in $\rho_{L}, \delta \rho_{L}>0\left(\delta \rho_{X}>0\right), \rho_{X<}$ is 


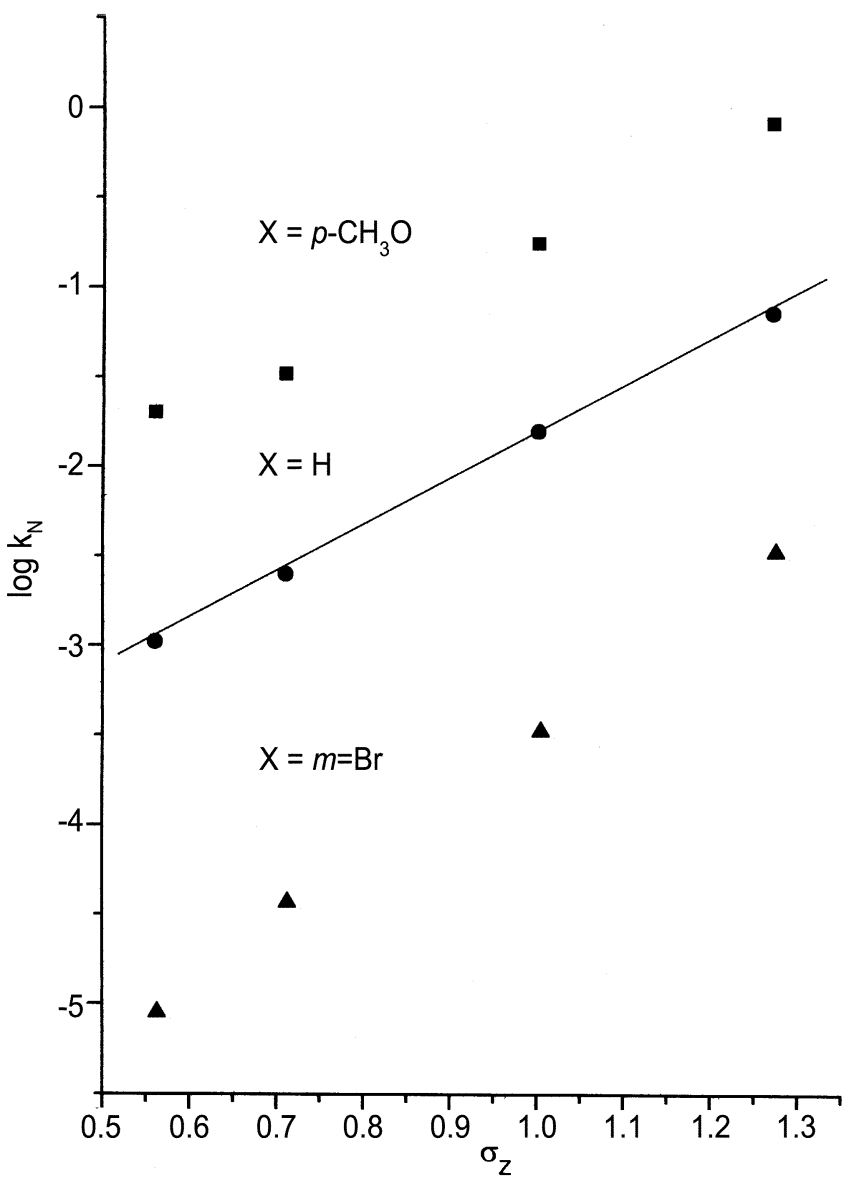

Figure 3. Ilammett plots $\left(\rho_{L}\right)$ for the pridinolysis of Z-ary cyclobutanecarboxylates with $\mathrm{X}$-py ridines $\left(\mathrm{XC}_{5} \mathrm{H}_{4} \mathrm{~N}\right)$ in $\mathrm{MeCN}$ at $55.0^{\circ} \mathrm{C}$.

Table 2. Activalion parameters for the reactions of $\%$-aryl cyclobutanecarboxylates w ith $\mathrm{X}$-psridines in acetonitrile

\begin{tabular}{|c|c|c|c|c|c|}
\hline$X$ & Z & Temp & $\begin{array}{c}k \\
\left(\times 10^{3} \mathrm{M}^{-1} \mathrm{~s}^{-1}\right)\end{array}$ & $\begin{array}{c}\Delta H^{\dot{r}} \\
\mathrm{kcal} \cdot \mathrm{mol}^{-1}\end{array}$ & $\begin{array}{c}-\Delta S^{\prime} \\
/ \mathrm{cal} \cdot \mathrm{mol}^{-1} \mathrm{~K}^{-1}\end{array}$ \\
\hline \multirow[t]{3}{*}{$p-\mathrm{ClH}_{3}$} & $m-\mathrm{CV}$ & 35 & 2.27 & $4.77 \pm 0.04$ & $55 \pm 2$ \\
\hline & & 45 & 2.95 & & \\
\hline & & 55 & 3.89 & & \\
\hline \multirow{3}{*}{$p-\mathrm{ClH}_{3}$} & $p-\mathrm{NO}_{2}$ & 35 & 211 & $5.23 \pm 0.05$ & $45 \pm I$ \\
\hline & & 45 & 282 & & \\
\hline & & 55 & 379 & & \\
\hline \multirow[t]{3}{*}{$m-\mathrm{Br}$} & $m-C \mathrm{~V}$ & 35 & 0.00429 & $5.09 \pm 0.05$ & $67 \pm 2$ \\
\hline & & 45 & 0.00571 & & \\
\hline & & 55 & 0.00759 & & \\
\hline \multirow[t]{3}{*}{$m-\mathrm{Br}$} & $p-\mathrm{VO}_{2}$ & 35 & 1.48 & $5.84 \pm 0.06$ & $53 \pm 1$ \\
\hline & & 45 & 2.04 & & \\
\hline & & 55 & 2.82 & & \\
\hline
\end{tabular}

"Calculated by the Eyring equation. Errors shown are standard deviations.

positive, eq. (2b). ${ }^{5.69 .16}$

We also note in Table 1 that the rate increase is invariably accompanied by a decrease in the selectivities, $\rho\left(\rho_{\mathrm{X}}\right.$ or $\left.\rho_{L}{ }^{-}\right)$, and hence the reactivity-selectivity principle (RSP) holds. ${ }^{14.17}$ Adherence to the RSP is considered another criterion for the stepwise mechanism with rate-limiting expulsion of the

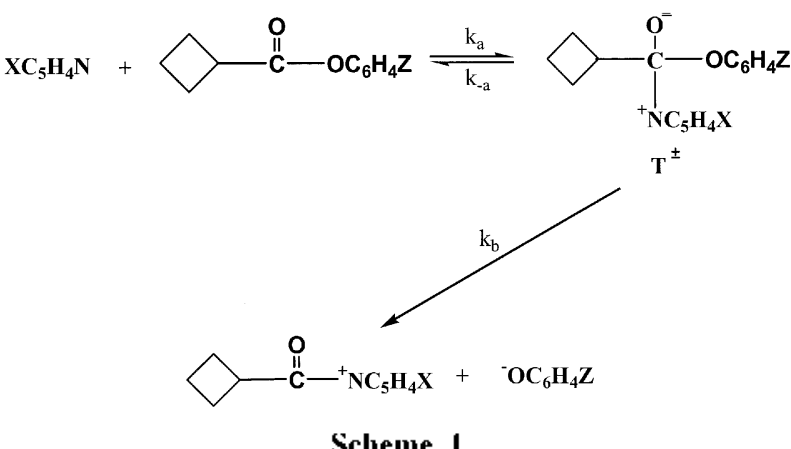

leaving group (aryl oxides). ${ }^{1 \cdot k \cdot 17}$

We have recently studied the kinetic isotope effects $\left(k_{k} \mid k_{b}\right)$ in acetonitrile for the reactions of 7.-aryl cyclobutanecarboxylates with $\mathrm{X}$-benzylamies deuterated on the nitrogen $\left(\mathrm{XC}_{6} \mathrm{H}_{4} \mathrm{CH}_{2} \mathrm{ND}_{2}\right)^{6}{ }^{6}$ We noted that the $k_{\mathrm{H}} / k_{\mathrm{b}}$, values were all greater than one $k_{1} / k_{\mathrm{D}}>1.0$, indicating that the rate-determining step was not a simple concerted $\mathrm{S} \& 2$ process (TS1), or a stepwise mechanism with a rate-limiting formation of a

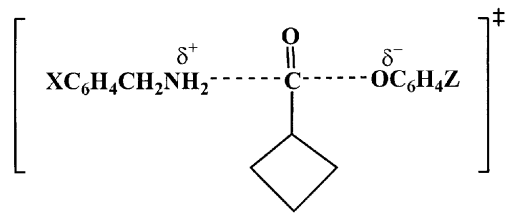

TS 1

tetrahedral intermediate (TS2) since in such cases inverse kinetic isotope effect, $k_{\mathrm{H}} / k_{\mathrm{b}}$, were expected due to an increase in the $\mathrm{N}-\mathrm{H}$ vibrational frequency as a result of steric congestion of the $\mathrm{N}-\mathrm{H}$ moiety in the bond making step. The kinetic isotope effects observed, $k_{1 /} / k_{\mathrm{L}}=1.19-1.46 .^{6}$ were larger than those expected from a stepwise acyl transfer mechanism, but were smaller than normal primary kinetic isotope effects. ${ }^{10 \mathrm{l} b}$ The $k_{1} / k_{\mathrm{L}}$ ) values were smaller for a stronger nucleophile and nucleofuge. Since in the intermediate, $\mathrm{I}$, both a stronger nucleophile and nucleofuge facilitate the leaving group departure, less assistance was needed in the rate-limiting leaving group departure by the hydrogen bonding of the amine hydrogen.

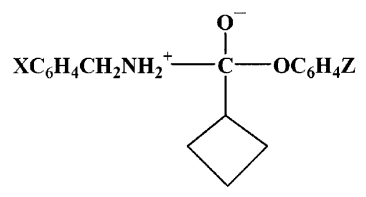

TS 2

Activation parameters for the reactions of aryl cyclobutanecarboxylates with pyridines are shown in Table 2 . The values of $\Delta H^{+}$, and $\Delta S^{+}$were obtained from the slope and intercept, respectively, of tyring plots, by least-squares analysis. Although the relatively low positive $\Delta H^{+}$and large negative $\Delta S^{+}$values are in line with the stepwise mechanism. ${ }^{\text {tc.y. }}{ }^{18}$ they can also be interpreted as supportive of a 
concerted mechanism.

Castro et $a l^{19}$ have argued and Lee et al. ${ }^{16:}$ have shown theoretically that a tetrahedral intermediate cannot be formed for a substrate with a strong electron donor acyl group. i.e. $\mathrm{C}_{2} \mathrm{H}_{3} \mathrm{O}$, due to the kinetic instability brought about by the large values of $k_{\mathrm{il}}$ and $k_{\mathrm{b}},{ }^{19.20}$ (Scheme 1). Thus a concerted mechanism is enforced. ${ }^{\left({ }^{4}\right) .20}$ However, for the reaction systems investigated in this work, the cyclobutane group has a relatively low resonance donor effect $\left(\sigma_{k}=-0.12 \mathrm{ws} .-0.44\right.$ for $\mathrm{C}_{2} \mathrm{H}_{3} \mathrm{O}$ group $)^{21}$ so that the $\mathrm{T}^{ \pm}$intermediate seems to be stable enough to lead to the proposed stepwise mechanism.

In summary, the reactions of aryl cyclobutanecarboxylates with pyridines in acetonitrile proceed by a stepwise mechanism in which the rate-determining step is the breakdown of the zwitterionic tetrahedral intermediate.

These mechanistic conclusions are drawn based on (i) the large magnitude of $\rho x$ and $\rho 7$, (ii) the positive sign of $\rho \times 7$. and the larger magnitude of $\rho \times z$. than that for normal $S_{1}: 2$ processes, (iii) a small positive enthalpy of activation, $\Delta I^{+}$, and a large negative entropy of activation, $\Delta S^{\prime}$, and lastly (iv) adherence to the reactivity-selectivity principle (RSP) in all cases.

\section{Experimental Section}

Materials. Merck GR acetonitrile was used after three distillations. The pyridine nucleophiles, Aldrich GR, were used without further purification. Reacting phenols with cyclobutanecarbonyl chloride prepared Aryl cyclobutanecarboxylates. The substrates synthesized were confirmed by spectral analyses as follows.

p-Cyanoaryl cyclobutanecarboxylate. $\delta_{1}(250 \mathrm{MHz}$. $\left.\mathrm{CDCl}_{3}\right) 7.25-7.70\left(4 \mathrm{H}, \mathrm{m}, \mathrm{C}_{6} \mathrm{H}_{4}\right), 3.5-3.6(1 \mathrm{H}, \mathrm{m}, \mathrm{CH}), 2.3-$ $2.5\left(4 \mathrm{H}, \mathrm{m}, 2 \mathrm{CH}_{2}\right), 1.9-2.1\left(2 \mathrm{H}, \mathrm{m}, \mathrm{CH}_{2}\right) ; v_{\text {max }}($ neat $) / \mathrm{cm}^{-1}$ $2900(\mathrm{CH}), 2300(\mathrm{CN}), 1730(\mathrm{C}=\mathrm{O}) ; \mathrm{m} / \mathrm{7}=201\left(\mathrm{M}^{-}\right)(\mathrm{Calc}$. for $\mathrm{C}_{12} \mathrm{H}_{11} \mathrm{NO}_{2} ; \mathrm{C}, 71,6 ; \mathrm{H}, 5.47$. Found: $\mathrm{C}, 71.7: \mathrm{H}, 5.46 \%$ ),

m-Cyanoaryl cyclobutancearboxylate. $\delta_{1}(250 \mathrm{MH}$. $\left.\mathrm{CDCl}_{3}\right) 7.25-7.70\left(4 \mathrm{H}, \mathrm{m}, \mathrm{C}_{6} \mathrm{H}_{4}\right), 3.5-3.6(1 \mathrm{H}, \mathrm{m}, \mathrm{CH}) .2 .3-$ $2.5\left(4 \mathrm{H}, \mathrm{m}, 2 \mathrm{CH}_{2}\right), 1.9-2.1\left(2 \mathrm{H}, \mathrm{m}, \mathrm{CH}_{2}\right) ; v_{\text {max }}($ neat $) / \mathrm{cm}^{-1}$ $2900(\mathrm{CH}), 2300(\mathrm{CN}), 1730(\mathrm{C}=\mathrm{O}) ; \mathrm{m} / \mathrm{z}=201\left(\mathrm{M}^{-}\right)(\mathrm{Calc}$. for $\mathrm{C}_{12} \mathrm{H}_{11} \mathrm{NO}_{2}: \mathrm{C}, 71.6 ; \mathrm{H}, 5.47$. Found: $\mathrm{C}, 71.7: \mathrm{H}, 5.46 \%$ ).

p-Nitroaryl cyclobutanecarboxylate. $\mathrm{Mp} 60-62{ }^{\circ} \mathrm{C} ; \delta_{1}$ $\left(250 \mathrm{MHz}, \mathrm{CDCl}_{3}\right) 7.24-7.80\left(4 \mathrm{H}, \mathrm{m}, \mathrm{C}_{6} \mathrm{H}_{4}\right), 3.4-3.6(\mathrm{lH}, \mathrm{m}$, CH), 2.3-2.6 (4H, m. 2 $\left.2 \mathrm{CH}_{2}\right), 2.0-2.2\left(2 \mathrm{H}, \mathrm{m}, \mathrm{CH}_{2}\right) ; v_{\max }$ $(\mathrm{KBr}) / \mathrm{cm}^{-1} 2900(\mathrm{CH}), 1730(\mathrm{C}=\mathrm{O}) ; \mathrm{m} / \mathrm{z}=221\left(\mathrm{M}^{-}\right)(\mathrm{Calc}$. for $\mathrm{C}_{11} \mathrm{H}_{11} \mathrm{NO}_{4} ; \mathrm{C}, 59.7 ; \mathrm{H}, 4.98$. round: $\mathrm{C}, 59.8: \mathrm{H}, 4.99 \%$ ).

$\boldsymbol{m}$-Nitroaryl cyclobutanecarboxylate. $\delta_{1}(250 \mathrm{MHz}$, $\left.\mathrm{CDCl}_{3}\right) 7.24-7.80\left(4 \mathrm{H}, \mathrm{m}, \mathrm{C}_{6} \mathrm{H}_{4}\right), 3.4-3.6(1 \mathrm{H}, \mathrm{m}, \mathrm{CH}), 2.3-$ $2.6\left(4 \mathrm{H}, \mathrm{m}, 2 \mathrm{CH}_{2}\right), 2.0-2.2\left(2 \mathrm{H}, \mathrm{m}, \mathrm{CH}_{2}\right) ; v_{\text {max }}$ (neat) $/ \mathrm{cm}^{-1} 2900$ $(\mathrm{CH}), 1730(\mathrm{C}=\mathrm{O}) ; \mathrm{m} / \mathrm{z}=221\left(\mathrm{M}^{-}\right)\left(\mathrm{Calc}\right.$. for $\mathrm{C}_{11} \mathrm{H}_{11} \mathrm{NO}_{4} ; \mathrm{C}$, $59.7 ; \mathrm{H}, 4.98$. Found: C. 59.8: H, 4.99\%).

p-Acetylaryl cyclobutanecarboxylate. $\delta_{1}(250 \mathrm{MHz}$, $\left.\mathrm{CDCl}_{3}\right) 7.25-7.70\left(4 \mathrm{H}, \mathrm{m}, \mathrm{C}_{6} \mathrm{H}_{4}\right), 3.5-3.6(1 \mathrm{H}, \mathrm{m}, \mathrm{CH}), 2.3-$ $2.5\left(4 \mathrm{H}, \mathrm{m}, 2 \mathrm{CH}_{2}\right), 1.9-2.1\left(2 \mathrm{H}, \mathrm{m}, \mathrm{CH}_{2}\right) ; v_{\text {ma }}$ (neat $) / \mathrm{cm}^{-1} 2900$ $(\mathrm{CH}), 1730(\mathrm{C}=\mathrm{O}) ; \mathrm{m} / \mathrm{z}=218\left(\mathrm{M}^{+}\right)\left(\mathrm{Calc}\right.$. for $\mathrm{C}_{1: \mathrm{H}} \mathrm{H}_{1+} \mathrm{O}_{3} ; \mathrm{C}$, 71.6; H, 6.42. Found: C. 71.6: $\mathrm{H}, 6.43 \%$ ).

Rate constants. Rates were measured conductimetrically

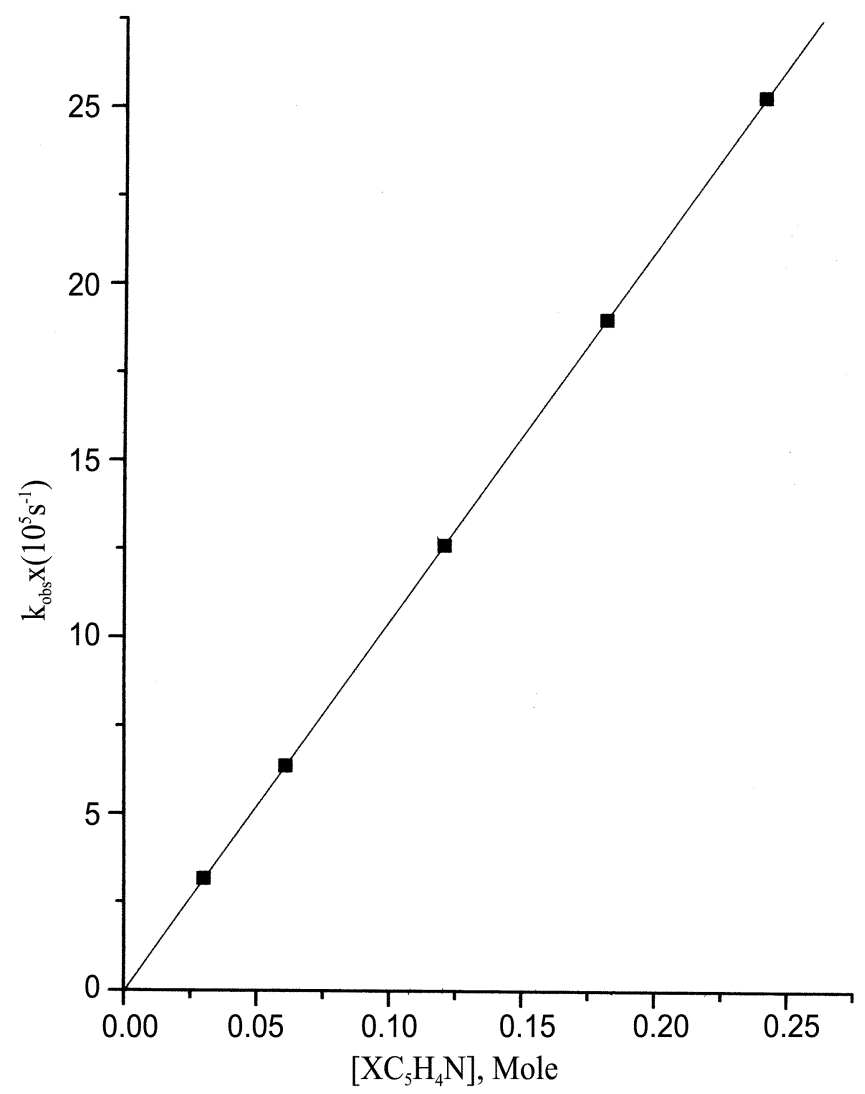

Figure 4. Plots of pseudo-fïst order rate constants $\left(k_{o_{3}}\right)$ vs nucleophile concentration. $\left[\mathrm{XC}_{5} \mathrm{H}_{4} \mathrm{~N}\right]$. for reactions of $m$-cyanoaryl caclobutanecarboxylate with $\mathrm{X}$-pyridine $(\mathrm{X} \mathrm{H})$ in acetonitrile at $55.0^{\circ} \mathrm{C}$.

at $55.0=0.05{ }^{\circ} \mathrm{C}$. The conductivity bridge used in this work was a self-made computer automatic $A / D$ converter conductivity bridge. Pseudo-first-order rate constants, $k_{\text {obs }}$, were determined by the curve fitting analysis of the computer data with a modified version of the Origin program, which fits conductance $v$ s. time data to the equation $\mathrm{A}=\mathrm{A} \cdot \mathrm{x} .+\left(\mathrm{A}_{0}-\right.$ $A$. $) \exp \left(-k_{\text {obs }} \times t\right)$, where $A$ is the observed conductivity and $\mathrm{A} \cdot \mathrm{A}_{\cup}-\mathrm{A} \cdot \mathrm{x}_{*}$ and $k_{\mathrm{ubs}}$ are iteratively optimized to achieve the best possible least-squares fit with a large excess of pyridine (Py); [aryl cyclobutanecarboxylate] $\approx 1 \times 10^{-3} \mathrm{M}$ and [Py] $=$ 0.03-0.24 M. Second-order rate constants, $k_{\mathrm{N}}$, were obtained from the slope of a plot of $k_{o b s} v s$. [Py] with more than five concentrations of pyridine, eq. 3, and Figure 4. The $k_{\mathrm{v}}$ values in Table 1 are the averages of more than three runs and were reproducible to within $\pm 3 \%$.

Product analysis. $p$-Nitroaryl cyclobutanecarboxylate was reacted with excess $p$-methylpyridine with stirring for more than 15 half-lives at $55.0^{\circ} \mathrm{C}$ in acetonitrile, and the products were isolated by evaporating the solvent under reduced pressure. The product mixture was separated by column chromatography (silica gel, $20 \%$ ethyl acetate$n$-hexane). Analysis of the products gave the following results.

Cyclobutyl-C $(=\mathbf{O}) \mathbf{N}^{+} \mathbf{C}_{5} \mathbf{H}_{\mathbf{4}} \boldsymbol{p}-\mathbf{C H}_{3} . \delta_{1}\left(250 \mathrm{MHz}, \mathrm{CDCl} l_{3}\right)$, 3.4-3.6 (1H, m, CH), 2.5-2.8 $\left(4 \mathrm{H}, \mathrm{m}, 2 \mathrm{CH}_{2}\right), 2.3(3 \mathrm{H}, \mathrm{m}$, $\left.\mathrm{CH}_{3}\right), 2.0-2.1\left(2 \mathrm{H}, \mathrm{m}, \mathrm{CH}_{2}\right) ; v_{\text {mavinat }} / \mathrm{cm}^{-1} 2900(\mathrm{CH}), 1730$ $(\mathrm{C}=\mathrm{O}) ; \mathrm{m} / \mathrm{z}=176\left(\mathrm{M}^{-}\right)$. (Calc. for $\mathrm{C}_{11} \mathrm{H}_{14} \mathrm{NO} ; \mathrm{C}, 75 ; \mathrm{H}$. 
7.95. Found : C. $74.9 ;$ H. $7.96 \%$ )

Acknowledgment. We thank the Korean Chemical Society and the Korean Science and Engineering Foundation (KCSKOSEF-2001-01) for support of this work.

\section{References}

1. Satterthwait. A. C: Jencks, W. P. J. Am. Chem. Soc. 1974, 96. 7018

2. (a) Koh. H. J.: Lee. H. C.: Lee. H. W.: Lee. I. Bull Korean Chem. Soc. 1995. 16. 839. (b) Castro. E. A.: Valdivia. J. L. J. Org Chem. $1986,51,1668$.

3. Gresser M. J. Jencks, W. P. J. Am. Chem. Soc. 1977, 99.6970

4. (a) Bond. P. M. Moodie R. B. J. Chem. Soc. Pertin Trans. 2 1976. 679. (b) Castro. E. A.: Gil. F. J. Am Chent Soc. 1977. 99. 7611. (c) Castro. E. A.: Freudenberg. M. J. Org. Chem. 1980. t5. 906. (d) Castro. E. A.: Ibanez. F.: Lagos. S.: Schick. M. : Santos. J. G. J. Org. Chem. 1992. 57.2691.

5. Koh, H. I.: Shin, C. H. Lee. H. W.: Lee, I. J. Chem. Soc. Parkin Troms. $21998,1329$.

6. Lee. H. W.: Yun. Y. S.: Lee. B. S.: Koh. H. J.: Lee. I. J. Chent. Soc., Perkin Trans. 2 2000. 2032.

7. (a) Page. M.: Williams. A. Organic and Bio-organic A fechanisns. Longman: Harlow: 1997, ch. 2. (b) Gresser, M. I. Jencks. W. P. J. Am. Chem Soc. 1997, 99,6963. (c) Palling. D. I. Jencks. W. P. J. Am. Chem. Soc. 1984. 106, 4869. (d) Castro. E. A.: Ureta. C.J. Org. Chem. 1990. 55.1676.

8. (a) Lee. I.: Lee. D.: Kim. C. K. J. Phws. Chent A 1997. 101. 879.

(b) Koh. H. J.: Han. K. L.: Lee. I. J. Org Chent. 1999. 64. 4783.

(c) Castro. E. A.: Ureta, C. J. Chem. Soc. Perkin Trams. 21991. 63.

9. (a) Koh, H. I.: Kim. S. I.: Lee. B. C.: Lee, I. J. Chem Soc.. Perkin Trons. 2 1996. 353. (b) Kim. T. H.: Hul. C.: Lee. B. S.: Lee. I. $J$. Chem. Soc. Perkin Trans. 2 1995. 2257. (c) Koh. H. J.: Lee. J. W.: Lee. H. W.: Lee. I. Con. J. Chen. 1998. 76. 710. (d) Koh. H. J.: Han, K. L.: Lee. J. W. Lee. I. J. Org (7hem. 1998. 63, 9834. (e) Koh. H. J.: Lee. J. W: Lee. H. W. Lee, I. New J. Chem. 1997. 21. 447. (f) Koh. H. J.: Kim. O. S.: Lee, J. W.: Lee, I. J. Plys. Org. Chem. 1997. 10.725 (g) Koh. H. J.: Kim. T. H.: Lee. B. S.: Lee. I. J. Chent. Res. 1996. (S) 482. (M) 2741.

10. (a) Lee. I. Adh: Phns. Org Chem. 1992. 27. 57. (b) Lee. I. Chem. Soc. Rev. 1995, 24, 223. (c) Isaacs. N. S. Phnsical Organic
Chemistru. $2^{\text {nd }}$ Ed.; Longman: Harlow: 1995: ch. 4

11. Lee. I.: Kim. C. K.: Han1. I. S.: Lee. H. W.: Kim. W. K.: Kim. Y. B. J. Pho Chem. B 1999. 103.7302

12. Spillane. W. T.: Hogan. G.: MeGrath. P.: King. J.: Brack. C. J Chem. Soc. Perkin Trans. 2 1996. 2099.

13. Reichardt, C. Solven and Solven Effects in Organic Chemistry $2^{\text {nd }}$ ed: VCH: Weinheim, 1988; Table A-1, p 408.

14. (a) Lee. I.: Choi. Y. H.: Lee. H. W: Lee. B. S. J. Chem. Soc Perkin Trams. 2 1988. 1537. (b) Gilliom. R. D. Introduction to Phsical Organic Chemism: Addison-Wesley: Reading. MA 1970: p 148. (c) Jacobson. B. M: Lewis, E. S. J. Org. Chem. 1988. 53, 46. (d) Siggel. M. R. F; Streitwieser, A., Jr; Thomas, T. D. J. Am Chem. Soc, 1988. 110,8022 . (e) Lee. I.; Lee. B. S.; Koh. H. T.: Chang. B. D. Bull. Korean Chen. Soc. 1995. 16. 277.

15. (a) Menger. F. M.: Stnith. T. H. J. Ant Chent. Soc. 1972. 94. 3824 (b) Buncel. E.: Unn. I. H. J. Chent. Soc. Chem. Commun. 1986 595. (c) Buncel, E.: Um. I. H.: Hoz, S. J. Am. Chem. Soc. 1989. 111, 791. (d) Kown. D. S.: Nahm. J. H.: Um. I. H. Bull. Konaon Chem. Soc 1994. 15, 654 (e) Um. I. H: Yoon. H. W: Lee J. S. Moon. H. T.: Kown. D. S. J. Ong. Chent 1997. 62. 5939. (f) Um. I. H.: Hong. Y. T.: Lee. Y. T. Bull. Korean Chent. Soc. 1998. 19. 147 (g) Unn. I. H.: Min. I. S.: Ahn. I. A.: Hahn. H. J. J. Org. Chent 2000. 65, 5659. (h) Um, I. H.; Kim. M. J.: Lee. H. W. Chem Commun. 2000. 2165. (i) Oh, H. K; Jeong. J. Bull. Korean Chem. Soc. 2001, 22, 1123 . (j) Oh. H. K.: Woo. S. Y.: Oh, C. H.: Park. Y. S.: Lee. I. J. Org. Chem 1997. 62. 5780 (k) Oh. H. K.: Kiml. S K.: Cho. I. H.: Lee. I. J. Chent. Soc. Perkin Trans. 2 2000. 2306.

16. (a) Lee. I. Bull. Korean Chent Soc 1994. 15. 985 (b) Lee. D. Kim. C. K.: Lee, I. Bull. Korean Chem. Soc. 1995, 16, 1203. (c) Lee, I; Lee D.: Kim, C. K. J. Phus. Chem. \& 1997, 101, 879

17. (a) Pross, A. Adv. Phys. Org. Chem 1977, 1t,69. (b) Exner, D. d. Chent. Soc. Perkin Trons. 2 1993. 973. (c) Buncel. E.: Wilson. H. J. Chent Educ. 1987. 6t. 475.

18. Neutonen. H. J. Chent. Scc., Pertin Trans. 2 1995. 951

19. (a) Castro. E. A.; Ibanez, F.: Salas. M.; Santos, J. G. J. Ong. Chem. 1991. 56. 4819. (b) Song, B. D.; Jencks. W. P. J. Am. Chem. Soc. 1989. 111. 8479

20. (a) Castro. E. A.: Salas. M. T.: Santos. I. G. J. Org. Chem. 1994. 59. 30. (b) Castro. E. A.: Cubillos. M.: Santos. T. G. J. Ong. Chent. 1996. 61.3501.

21. Exner, O. In Comlation Anatysis in Chemistry Recent Adances, Chapman, N. B., Shorter. J.. Eds.; Plenum Press: New York, 1978: ch. 10 . 